\title{
ANALISIS CLUSTER K-MEANS KABUPATEN/KOTA DI JAWA TIMUR BERDASARKAN LEVEL EPIDEMIK HIV
}

\section{CLUSTER K-MEANS ANALYSIS OF THE HIV EPIDEMIC LEVEL IN THE CITIES OF EAST JAVA}

\author{
Desy Yuanita Nugroho ${ }^{1}$, Arief Wibowo ${ }^{2}$ \\ 1,2Departemen Biostatistika dan Kependudukan \\ Fakultas Kesehatan Masyarakat Universitas Airlangga \\ Jl. Mulyorejo Kampus C Unair Surabaya, Jawa Timur 60115, Indonesia \\ Alamat korespondensi: Desy Yuanita Nugroho \\ E-mail: desy.yuanita.nugroho-2015@fkm.unair.ac.id
}

\begin{abstract}
Human Immunodeficiency Virus (HIV) in East Java was not only occurred in urban areas. This is due to the population mobility and sexual lifestyles. This study aimed to classify districts/cities in East Java used Cluster $K$-Means analysis based on the number of high risk population that living with HIV. This study was an observational study with an analytical method. The secondary data was taken from HIV and PIMS Situation Report of the East Java Provincial Health in 2017. This study obtained 3 optimal clusters, which were 4 districts/cities in cluster 1 named alert category, 24 districts/cities in cluster 2 named standby category and 10 districts/cities in cluster 3 named alert category. Proposed suggestions based on this study were prioritized early HIV test and counseling, provided adequate care, support and treatment for people living with HIV.
\end{abstract}

Keywords: human immunodeficiency virus, key population, cluster k-means

\begin{abstract}
ABSTRAK
Penyakit Human Immunodeficiency Virus (HIV) di Jawa Timur tidak hanya berkumpul di wilayah perkotaan saja. Hal ini disebabkan karena adanya implikasi dari mobilitas penduduk dan gaya hidup seksual. Penelitian ini bertujuan untuk mengelompokkan kabupaten/kota di Jawa Timur menggunakan metode analisis kluster k-means berdasarkan jumlah populasi risiko tinggi yang mengidap HIV. Metode penelitian yang diterapkan adalah metode analitik dan jenis penelitian observasional. Data Laporan Situasi HIV dan PIMS dari Dinas Kesehatan Provinsi Jawa Timur tahun 2017 digunakan dalam penelitian ini sebagai unit analisis sehingga disebut penelitian dengan data sekunder. Penelitian ini menyimpulkan bahwa terdapat 3 kluster optimal yang terbentuk yaitu cluster 1 dengan anggota sebanyak 4 kabupaten/kota termasuk kategori waspada, cluster 2 dengan anggota sebanyak 24 kabupaten/ kota termasuk kategori siaga dan cluster 3 dengan anggota sebanyak 10 kabupaten/kota termasuk kategori awas. Usulan yang dapat diberikan berdasarkan hasil penelitian ini adalah memprioritaskan skrining/tes dan konseling HIV berdasarkan jumlah populasi kunci yang mengidap HIV serta penyediaan layanan perawatan, dukungan dan pengobatan yang memadai.
\end{abstract}

Kata kunci: human immunodeficiency virus, populasi kunci, cluster k-means

\section{PENDAHULUAN}

HIV merupakan retrovirus yang menyerang system imunitas tubuh manusia sehingga penyakit bawaan lainnya mudah menyerang (Kemenkes RI, 2010). Penderita HIV terus bertambah dan menjadi masalah kesehatan yang harus segera diatasi. Pesatnya penularan HIV juga terjadi di dunia sehingga kebijakan penanggulangan HIV/AIDS dituangkan dalam SDG's poin ketiga. Penyebaran HIV perlu untuk segera ditangani karena orang yang terinfeksi HIV akan mempunyai dampak yang luas dan 
kompleks baik masalah fisik, psikologis maupun sosial (Gusty, Farlina dan Alfitri, 2015).

Penyakit HIV dapat ditularkan melalui hubungan seksual yang berisiko misalnya homoseksual, dan berganti-ganti pasangan, penggunaan obat-obatan dengan alat injeksi yang sama, transfusi darah dari pendonor yang terinfeksi serta penularan perinatal dari ibu ke anak. Saat ini, lebih banyak cara yang tersedia untuk mencegah penularan HIV salah satunya yaitu tidak melakukan hubungan seks yang berisiko, setia terhadap pasangan seksual, dan tidak berbagi jarum suntik.

World Health Organization (WHO) mencatat pada tahun 2016, jumlah penderita Acquired Immunodeficiency Syndrome (HIV) di dunia sebesar 36,9 juta orang, dan dilaporkan virus HIV telah memakan korban meninggal dunia yaitu 1,2 juta orang. Sedangkan di Indonesia, berdasarkan data Laporan Perkembangan HIV Kemenkes RI, dari tahun 2009 hingga Desember 2017 jumlah kumulatif pengidap HIV sebanyak 280.623 kasus dan banyak berkumpul di provinsi besar Indonesia (Kemenkes RI, 2017).

Situasi perkembangan HIV/AIDS digambarkan dengan level epidemik yang telah ditetapkan oleh WHO yaitu level epidemik rendah, epidemik terkonsentrasi dan epidemik meluas. Akan tetapi, cara tersebut hanya diterapkan untuk wilayah provinsi saja. Perlu dilakukan analisis untuk mengelompokkan wilayah kabupaten/kota berdasarkan level epidemik HIV sehingga pengendalian HIV bisa lebih cepat diatasi oleh pemerintah kabupaten/ kota. Berdasarkan latar belakang tersebut, maka penelitian ini dilakukan untuk mengelompokkan kabupaten/kota di Jawa Timur berdasarkan jumlah populasi kunci yang mengidap HIV.

\section{METODE PENELITIAN}

Penelitian ini bertujuan untuk mengelompokkan populasi kunci yang mengidap HIV berdasarkan persentasenya menurut ketetapan WHO. Level epidemik HIV menurut ketetapan WHO adalah $\leq 1 \%$ populasi kunci yang mengidap HIV termasuk level epidemik rendah, $>1 \%$ populasi kunci yang mengidap HIV termasuk level epidemik terkonsentrasi sedangkan $\geq 1 \%$ ibu hamil yang mengidap HIV termasuk level epidemik meluas.

Unit analisis dalam penelitian ini adalah seluruh kabupaten/kota di Provinsi Jawa Timur yaitu sebanyak 38. Data sekunder yang digunakan dalam penelitian ini adalah data Laporan Situasi Perkembangan HIV dan PIMS dari Dinas Kesehatan Provinsi Jawa Timur tahun 2017. Variabel penelitian adalah prevalensi HIV pada ibu hamil, prevalensi HIV pada wanita penjaja seks, prevalensi HIV pada waria, prevalensi HIV pada lelaki seks lelaki, prevalensi HIV pada pasangan risiko tinggi, prevalensi HIV pada pelanggan penjaja seks dan prevalensi HIV pada penasun. Data tersebut akan dianalisis menggunakan metode Cluster K-Means dengan bantuan aplikasi MINITAB dan SPSS.

Prevalensi HIV pada ibu hamil tertinggi di Kota Probolinggo yaitu sebesar $1,56 \%$ atau 13 orang dari 837 orang yang diperiksa. Prevalensi HIV pada wanita penjaja seks tertinggi berada di Kabupaten Tuban sebesar 100\% dari 9 orang yang diperiksa dan di Kota Blitar sebesar $100 \%$ dari 1 orang yang diperiksa. Selanjutnya prevalensi HIV pada pengguna napza suntik tertinggi berada di Kabupaten Malang sebesar $50 \%$ atau 1 orang dari 3 orang yang diperiksa dan Kabupaten Situbondo sebesar $50 \%$ atau 1 orang dari 2 orang yang diperiksa. Prevalensi HIV pada waria tertinggi berada di Kabupaten Bojonegoro sebesar $100 \%$ dari 5 orang yang diperiksa, Kabupaten Bondowoso sebesar $100 \%$ dari 2 orang yang diperiksa dan Kabupaten Trenggalek sebesar $100 \%$ dari 1 orang yang telah diperiksa. Prevalensi HIV pada lelaki seks lelaki tertinggi berada di Kabupaten Lumajang sebesar 100\% dari 6 orang yang telah diperiksa dan Kabupaten Tuban sebesar $100 \%$ dari 2 orang yang telah diperiksa. Prevalensi HIV pada pasangan risiko tinggi berada di Kota Batu sebesar 100\% dari 1 orang yang telah diperiksa. Prevalensi HIV pada pelanggan penjaja seks tertinggi berada di Kabupaten Bangkalan sebesar 100\% dari 1 orang yang telah diperiksa, Kabupaten Bondowoso sebesar $100 \%$ dari 2 orang yang telah diperiksa, Kabupaten Lumajang sebesar 100\% dari 77 orang yang telah diperiksa dan Kabupaten Ngawi sebesar $100 \%$ dari 2 orang yang telah diperiksa. 
Menurut Gudono (2014), dalam analisis Cluster K-Means ada dua asumsi yang harus dipenuhi, yaitu sampel mencerminkan populasi yang dapat dilakukan dengan uji Kaiser Mayer Olkin (KMO), apabila nilai KMO diantara 0,5 sampai 1 maka sampel dapat dikatakan mewakili populasi atau sampel representative. Asumsi selanjutnya yaitu tidak terjadi multikoliniearitas dapat menggunakan uji Bartlett's of Sphericity, apabila nilai $p$-value $>\alpha=0,05$, maka tolak $\mathrm{H}_{0}$ sehingga tidak terdapat hubungan antar variabel (tidak terjadi multikolinearitas).

Jika terjadi multikolinearitas, maka harus dilakukan penanganan terhadap multikolinearitas. Principal Component Analysis (PCA) merupakan metode yang dapat digunakan untuk mengatasi masalah multikolinearitas (Soemartini, 2008).

\section{HASIL PENELITIAN}

\section{Analisis Variabel Penelitian}

\section{Prevalensi HIV pada Ibu Hamil}

Prevalensi HIV pada ibu hamil dan dinyatakan dalam persentase di setiap kabupaten/kota di Jawa Timur disajikan melalui Tabel 1. Menurut level epidemik yang telah ditetapkan oleh WHO pada indikator ibu hamil, Jawa Timur bisa saja termasuk dalam level epidemik terkonsentrasi karena prevalensi HIV pada ibu hamil sebesar $<1 \%$ akan tetapi hal tersebut harus didukung dengan prevalensi HIV pada sub populasi kunci yang lain. Kota Probolinggo memiliki prevalensi HIV pada ibu hamil telah diperiksa yang cukup tinggi yaitu $1,56 \%$, sementara kabupaten/kota lain memiliki prevalensi yang rendah yaitu $<1 \%$.

\section{Prevalensi HIV pada Wanita Penjaja Seks}

Prevalensi HIV pada wanita penjaja seks dan dinyatakan dalam persentase di setiap kabupaten/ kota di Jawa Timur disajikan melalui Tabel 2. Provinsi Jawa Timur pada tahun 2017 memiliki prevalensi HIV pada WPS sangat tinggi yaitu $13,47 \%$. Apabila dikategorikan berdasarkan level epidemik HIV oleh WHO, Jawa Timur sudah termasuk dalam level epidemik terkonsentrasi karena prevalensi HIV pada ibu hamil sebesar $<1 \%$ dan sub populasi kunci yaitu WPS memiliki
Tabel 1. Prevalensi HIV pada Ibu Hamil di Jawa Timur Tahun 2017

\begin{tabular}{|c|c|c|}
\hline Kabupaten/Kota & Jumlah & Persentase \\
\hline Kota Probolinggo & 13 & 1,56 \\
\hline Kab. Jombang & 61 & 0,76 \\
\hline Kab. Bondowoso & 20 & 0,67 \\
\hline Kab. Tuban & 16 & 0,48 \\
\hline Kab. Lumajang & 9 & 0,45 \\
\hline Kab. Madiun & 3 & 0,43 \\
\hline Kab. Probolinggo & 26 & 0,43 \\
\hline Kab. Situbondo & 24 & 0,32 \\
\hline Kab. Tulungagung & 23 & 0,29 \\
\hline Kab. Pasuruan & 21 & 0,28 \\
\hline Kab. Banyuwangi & 48 & 0,28 \\
\hline Kab. Mojokerto & 16 & 0,23 \\
\hline Kota Malang & 12 & 0,22 \\
\hline Kab. Sidoarjo & 36 & 0,22 \\
\hline Kota Kediri & 6 & 0,17 \\
\hline Kota Surabaya & 56 & 0,17 \\
\hline Kab. Trenggalek & 7 & 0,16 \\
\hline Kab. Jember & 42 & 0,16 \\
\hline Kab. Lamongan & 16 & 0,16 \\
\hline Kota Pasuruan & 3 & 0,15 \\
\hline Kota Blitar & 4 & 0,15 \\
\hline Kota Mojokerto & 2 & 0,14 \\
\hline Kab. Bojonegoro & 5 & 0,13 \\
\hline Kab. Blitar & 13 & 0,12 \\
\hline Kab. Madiun & 3 & 0,12 \\
\hline Kab. Malang & 23 & 0,12 \\
\hline Kab. Gresik & 13 & 0,11 \\
\hline Kab. Kediri & 26 & 0,11 \\
\hline Kab. Magetan & 8 & 0,11 \\
\hline Kab. Ngawi & 9 & 0,11 \\
\hline Kab. Sumenep & 5 & 0,09 \\
\hline Kota Batu & 1 & 0,08 \\
\hline Kab. Nganjuk & 9 & 0,08 \\
\hline Kab. Pacitan & 3 & 0,07 \\
\hline Kab. Ponorogo & 3 & 0,05 \\
\hline Kab. Bangkalan & 2 & 0,04 \\
\hline Kab. Pamekasan & 0 & 0 \\
\hline Kab. Sampang & 0 & 0 \\
\hline Rata-rata & & 0,24 \\
\hline
\end{tabular}

Sumber:Laporan Situasi Perkembangan HIV dan AIDS Dinas Kesehatan Provinsi Jawa Timur Tahun 2017 
Tabel 2. Prevalensi HIV pada Wanita Penjaja Seks di Jawa Timur Tahun 2017

\begin{tabular}{|c|c|c|}
\hline Kabupaten/Kota & Jumlah & Persentase \\
\hline Kab. Tuban & 13 & 100 \\
\hline Kota Blitar & 61 & 100 \\
\hline Kab. Blitar & 20 & 66,67 \\
\hline Kab. Bojonegoro & 16 & 50 \\
\hline Kab. Lumajang & 9 & 29,47 \\
\hline Kab. Magetan & 3 & 25 \\
\hline Kab. Situbondo & 26 & 17,05 \\
\hline Kota Mojokerto & 24 & 12,50 \\
\hline Kab. Probolinggo & 23 & 12 \\
\hline Kab. Nganjuk & 21 & 11,33 \\
\hline Kab. Trenggalek & 48 & 8,40 \\
\hline Kab. Jember & 16 & 8,35 \\
\hline Kab. Pasuruan & 12 & 8,13 \\
\hline Kab. Banyuwangi & 36 & 7,58 \\
\hline Kab. Sumenep & 6 & 7,14 \\
\hline Kota Batu & 56 & 6,98 \\
\hline Kab. Sidoarjo & 7 & 6,71 \\
\hline Kab. Pacitan & 42 & 5,56 \\
\hline Kab. Tulungagung & 16 & 5,55 \\
\hline Kab. Ponorogo & 3 & 5,49 \\
\hline Kab. Madiun & 4 & 3,74 \\
\hline Kota Madiun & 2 & 2,77 \\
\hline Kota Kediri & 5 & 2.59 \\
\hline Kab. Malang & 13 & 2,59 \\
\hline Kab. Kediri & 3 & 2,19 \\
\hline Kota Malang & 23 & 2,18 \\
\hline Kota Surabaya & 13 & 1,7 \\
\hline Kab. Bangkalan & 26 & 0 \\
\hline Kab. Gresik & 8 & 0 \\
\hline Kab. Bondowoso & 9 & 0 \\
\hline Kab. Jombang & 5 & 0 \\
\hline Kota Pasuruan & 1 & 0 \\
\hline Kab. Lamongan & 9 & 0 \\
\hline Kota Probolinggo & 3 & 0 \\
\hline Kab. Mojokerto & 3 & 0 \\
\hline Kab. Ngawi & 2 & 0 \\
\hline Kab. Pamekasan & 0 & 0 \\
\hline Kab. Sampang & 0 & 0 \\
\hline Rata-rata & & 13,47 \\
\hline
\end{tabular}

Sumber: Laporan Situasi Perkembangan HIV dan AIDS Dinas Kesehatan Provinsi Jawa Timur Tahun 2017 prevalensi HIV $\geq 5 \%$ yaitu sebesar $13,47 \%$. Kabupaten Tuban dan Kota Blitar memiliki prevalensi HIV $100 \%$ yang artinya seluruh populasi WPS diperiksa yang ada di kabupaten dan kota tersebut mengidap HIV.

\section{Prevalensi HIV pada Penasun}

Prevalensi HIV pada penasun dan dinyatakan dalam persentase di setiap kabupaten/kota di Jawa Timur disajikan melalui Tabel 3. Prevalensi HIV pada penasun di Jawa Timur pada tahun 2017 memiliki rata-rata 5,19\%. Jawa Timur termasuk dalam level epidemik terkonsentrasi karena memiliki prevalensi HIV pada sub penasun sebesar $5,19 \%(\geq 5 \%)$. Kabupaten Situbondo memiliki prevalensi HIV pada penasun paling tinggi yaitu $50 \%$ yang artinya separuh dari populasi penasun di kabupaten tersebut mengidap HIV.

\section{Prevalensi HIV pada Waria}

Prevalensi HIV pada waria dan dinyatakan dalam persentase di setiap kabupaten/kota di Jawa Timur disajikan melalui Tabel 4. Provinsi Jawa Timur pada tahun 2017 memiliki prevalensi HIV pada waria sangat tinggi yaitu $15,23 \%$. Berdasarkan level epidemik HIV, Jawa Timur termasuk dalam level epidemik terkonsentrasi karena prevalensi HIV waria yang sudah diperiksa sebesar 15,23\% ( $\geq 5 \%)$. Kabupaten Bojonegoro, Bondowoso dan Trenggalek memiliki prevalensi HIV pada waria sebesar $100 \%$ yang artinya seluruh populasi waria di kabupaten tersebut mengidap HIV.

\section{Prevalensi HIV pada Lelaki seks Lelaki}

Prevalensi HIV pada lelaki seks lelaki dan dinyatakan dalam persentase di setiap kabupaten/ kota di Jawa Timur disajikan melalui Tabel 5. Prevalensi HIV pada lelaki seks lelaki di Provinsi Jawa Timur pada tahun 2017 sebesar 22,06\%. Berdasarkan level epidemik HIV, Jawa Timur termasuk dalam level epidemik terkonsentrasi karena prevalensi HIV pada lelaki seks lelaki yang sudah diperiksa sebesar $\geq 5 \%$. Kabupaten Lumajang dan Kabupaten Tuban memiliki prevalensi HIV pada lelaki seks lelaki sebesar 
Tabel 3. Prevalensi HIV pada Penasun di Jawa Timur Tahun 2017

\begin{tabular}{|c|c|c|}
\hline Kabupaten/Kota & Jumlah & Persentase \\
\hline Kab. Malang & 1 & 50 \\
\hline Kab. Situbondo & 1 & 50 \\
\hline Kab. Pasuruan & 14 & 47,06 \\
\hline Kab. Lamongan & 3 & 19,23 \\
\hline Kota Surabaya & 32 & 12.40 \\
\hline Kab. Sidoarjo & 9 & 10,98 \\
\hline Kab. Bangkalan & 3 & 2,56 \\
\hline Kota Malang & 9 & 2,27 \\
\hline Kota Madiun & 3 & 1,82 \\
\hline Kab. Banyuwangi & 2 & 0,91 \\
\hline Kab. Jombang & 0 & 0 \\
\hline Kab. Bojonegoro & 0 & 0 \\
\hline Kab. Blitar & 0 & 0 \\
\hline Kab. Bondowoso & 0 & 0 \\
\hline Kota Mojokerto & 0 & 0 \\
\hline Kab. Gresik & 0 & 0 \\
\hline Kota Probolinggo & 0 & 0 \\
\hline Kab. Jember & 0 & 0 \\
\hline Kota Batu & 0 & 0 \\
\hline Kab. Kediri & 0 & 0 \\
\hline Kota Blitar & 0 & 0 \\
\hline Kab. Lumajang & 0 & 0 \\
\hline Kota Kediri & 0 & 0 \\
\hline Kab. Madiun & 0 & 0 \\
\hline Kota Pasuruan & 0 & 0 \\
\hline Kab. Magetan & 0 & 0 \\
\hline Kab. Mojokerto & 0 & 0 \\
\hline Kab. Ponorogo & 0 & 0 \\
\hline Kab. Nganjuk & 0 & 0 \\
\hline Kab. Tulungagung & 0 & 0 \\
\hline Kab. Ngawi & 0 & 0 \\
\hline Kab. Tuban & 0 & 0 \\
\hline Kab. Pacitan & 0 & 0 \\
\hline Kab. Trenggalek & 0 & 0 \\
\hline Kab. Pamekasan & 0 & 0 \\
\hline Kab. Probolinggo & 0 & 0 \\
\hline Kab. Sampang & 0 & 0 \\
\hline Kab. Sumenep & 0 & 0 \\
\hline Rata-rata & & 5,19 \\
\hline
\end{tabular}

Sumber: Laporan Situasi Perkembangan HIV dan AIDS Dinas Kesehatan Provinsi Jawa Timur Tahun 2017
Tabel 4. Prevalensi HIV pada Waria di Jawa Timur Tahun 2017

\begin{tabular}{|c|c|c|}
\hline Kabupaten/Kota & Jumlah & Persentase \\
\hline Kab. Bojonegoro & 5 & 100 \\
\hline Kab. Bondowoso & 2 & 100 \\
\hline Kab. Trenggalek & 1 & 100 \\
\hline Kab. Blitar & 1 & 50 \\
\hline Kab. Situbondo & 2 & 40 \\
\hline Kab. Pasuruan & 4 & 33,33 \\
\hline Kota Mojokerto & 7 & 15,91 \\
\hline Kab. Tulungagung & 24 & 15,48 \\
\hline Kab. Ponorogo & 7 & 13,46 \\
\hline Kab. Banyuwangi & 12 & 13,04 \\
\hline Kab. Jember & 17 & 12,98 \\
\hline Kab. Gresik & 5 & 12,50 \\
\hline Kab. Nganjuk & 1 & 12,50 \\
\hline Kab. Malang & 14 & 10,61 \\
\hline Kota Madiun & 2 & 10 \\
\hline Kota Pasuruan & 3 & 8,57 \\
\hline Kota Malang & 3 & 8,33 \\
\hline Kota Kediri & 3 & 6,67 \\
\hline Kab. Sidoarjo & 8 & 4,76 \\
\hline Kota Batu & 2 & 4,17 \\
\hline Kab. Kediri & 6 & 4,14 \\
\hline Kota Surabaya & 13 & 2,16 \\
\hline Kab. Bangkalan & 0 & 0 \\
\hline Kab. Jombang & 0 & 0 \\
\hline Kota Blitar & 0 & 0 \\
\hline Kota Probolinggo & 0 & 0 \\
\hline Kab. Lamongan & 0 & 0 \\
\hline Kab. Tuban & 0 & 0 \\
\hline Kab. Lumajang & 0 & 0 \\
\hline Kab. Sumenep & 0 & 0 \\
\hline Kab. Madiun & 0 & 0 \\
\hline Kab. Sampang & 0 & 0 \\
\hline Kab. Magetan & 0 & 0 \\
\hline Kab. Mojokerto & 0 & 0 \\
\hline Kab. Probolinggo & 0 & 0 \\
\hline Kab. Ngawi & 0 & 0 \\
\hline Kab. Pacitan & 0 & 0 \\
\hline Kab. Pamekasan & 0 & 0 \\
\hline Rata-rata & & 15,23 \\
\hline
\end{tabular}

Sumber: Laporan Situasi Perkembangan HIV dan AIDS Dinas Kesehatan Provinsi Jawa Timur Tahun 2017 
Tabel 5. Prevalensi HIV pada Lelaki Seks Lelaki di Jawa Timur Tahun 2017

\begin{tabular}{|c|c|c|}
\hline Kabupaten/Kota & Jumlah & Persentase \\
\hline Kab. Lumajang & 6 & 100 \\
\hline Kab. Tuban & 2 & 100 \\
\hline Kab. Bojonegoro & 2 & 66,67 \\
\hline Kab. Ngawi & 2 & 66,67 \\
\hline Kab. Blitar & 5 & 55,56 \\
\hline Kota Blitar & 5 & 45,45 \\
\hline Kota Madiun & 14 & 42,42 \\
\hline Kab. Sumenep & 2 & 40 \\
\hline Kab. Probolinggo & 3 & 33,33 \\
\hline Kab. Nganjuk & 4 & 28,57 \\
\hline Kab. Sidoarjo & 66 & 22,30 \\
\hline Kab. Madiun & 2 & 20 \\
\hline Kota Surabaya & 187 & 18,95 \\
\hline Kab. Gresik & 7 & 18,42 \\
\hline Kab. Pasuruan & 10 & 18,18 \\
\hline Kab. Malang & 8 & 16,33 \\
\hline Kota Mojokerto & 8 & 15,38 \\
\hline Kab. Tulungagung & 67 & 14,26 \\
\hline Kab. Banyuwangi & 35 & 13,53 \\
\hline Kab. Mojokerto & 6 & 13,33 \\
\hline Kota Pasuruan & 9 & 11,25 \\
\hline Kota Malang & 120 & 11,06 \\
\hline Kab. Jombang & 5 & 10,42 \\
\hline Kab. Jember & 59 & 9,58 \\
\hline Kab. Kediri & 21 & 9,42 \\
\hline Kota Kediri & 42 & 8,84 \\
\hline Kab. Ponorogo & 5 & 8,51 \\
\hline Kab. Bangkalan & 0 & 0 \\
\hline Kab. Trenggalek & 0 & 0 \\
\hline Kab. Bondowoso & 0 & 0 \\
\hline Kota Batu & 0 & 0 \\
\hline Kota Probolinggo & 0 & 0 \\
\hline Kab. Lamongan & 0 & 0 \\
\hline Kab. Magetan & 0 & 0 \\
\hline Kab. Pacitan & 0 & 0 \\
\hline Kab. Situbondo & 0 & 0 \\
\hline Kab. Pamekasan & 0 & 0 \\
\hline Kab. Sampang & 0 & 0 \\
\hline Rata-rata & & 22,06 \\
\hline
\end{tabular}

Sumber:Laporan Situasi Perkembangan HIV dan AIDS Dinas Kesehatan Provinsi Jawa Timur Tahun 2017
$100 \%$ yang artinya seluruh populasi lelaki seks lelaki di kabupaten tersebut mengidap HIV.

\section{Prevalensi HIV pada Pasangan Berisiko Tinggi}

Prevalensi HIV pada pasangan berisiko tinggi dan dinyatakan dalam persentase di setiap kabupaten/kota di Jawa Timur disajikan melalui Tabel 6. Prevalensi HIV pada pasangan berisiko tinggi di Jawa Timur pada tahun 2017 sebesar 24,52\%. Berdasarkan level epidemik HIV, Jawa Timur termasuk dalam level epidemik terkonsentrasi karena prevalensi HIV pasangan risiko tinggi yang sudah diperiksa sebesar 24,52\% ( $\geq 5 \%$ ). Prevalensi HIV pada pasangan berisiko tinggi di Kota Batu sebesar 100\% yang artinya seluruh populasi pasangan berisiko tinggi di kota tersebut mengidap HIV.

\section{Prevalensi HIV pada Pelanggan Penjaja Seks}

Prevalensi HIV pada pelanggan penjaja seks dan dinyatakan dalam persentase di setiap kabupaten/kota di Jawa Timur disajikan melalui Tabel 7. Berdasarkan level epidemik HIV, Jawa Timur sudah termasuk dalam level epidemik terkonsentrasi karena prevalensi HIV pada pasangan risiko tinggi yang sudah diperiksa sebesar 24,52 ( $\geq 5 \%$ ). Prevalensi HIV pada pelanggan penjaja seks paling tinggi berada di Kabupaten Bangkalan, Bondowoso, Lumajang dan Ngawi sebesar $100 \%$ yang artinya seluruh populasi pelanggan penjaja seks di kabupaten tersebut mengidap HIV.

\section{Pengujian Asumsi Cluster K-Means}

Data dalam penelitian ini adalah berskala data rasio dan ukuran satuan pada variabel yang diteliti adalah sama atau tidak berbeda, sehingga tidak perlu dilakukan standarisasi data (Ong, 2013; Rivani, 2010; Muningsih and Kiswati, 2015; Borkowska-Niszczota, 2015).

Berdasarkan Tabel 8 diketahui bahwa nilai KMO adalah 0,659 dimana $0,5 \leq \mathrm{KMO}=0,66 \leq 1$, artinya data dapat digunakan untuk melakukan analisis cluster atau asumsi sampel representatif terpenuhi. Asumsi selanjutnya adalah mendeteksi multikolinearitas atau hubungan antar variabel dengan menggunakan uji Bartlett's of Sphericity. 
Tabel 6. Prevalensi HIV pada Pasangan Risiko Tinggi di Jawa Timur Tahun 2017

\begin{tabular}{|c|c|c|}
\hline Kabupaten/Kota & Jumlah & Persentase \\
\hline Kota Batu & 1 & 100 \\
\hline Kab. Ponorogo & 12 & 85,71 \\
\hline Kab. Lumajang & 74 & 75,51 \\
\hline Kab. Ngawi & 5 & 71,43 \\
\hline Kab. Probolinggo & 30 & 57,69 \\
\hline Kab. Trenggalek & 9 & 47,37 \\
\hline Kab. Magetan & 5 & 35,71 \\
\hline Kota Madiun & 60 & 35,50 \\
\hline Kab. Situbondo & 13 & 34,21 \\
\hline Kab. Bondowoso & 4 & 33,33 \\
\hline Kota Pasuruan & 2 & 33,33 \\
\hline Kab. Nganjuk & 7 & 30,43 \\
\hline Kab. Blitar & 19 & 27,54 \\
\hline Kab. Tulungagung & 36 & 24,32 \\
\hline Kab. Banyuwangi & 37 & 23,08 \\
\hline Kab. Tuban & 26 & 22,61 \\
\hline Kab. Sidoarjo & 45 & 21,74 \\
\hline Kota Mojokerto & 8 & 19,05 \\
\hline Kab. Gresik & 11 & 18,37 \\
\hline Kab. Mojokerto & 11 & 16,67 \\
\hline Kab. Malang & 21 & 14,29 \\
\hline Kota Surabaya & 55 & 13,51 \\
\hline Kab. Pasuruan & 56 & 13,29 \\
\hline Kota Malang & 71 & 12,28 \\
\hline Kab. Madiun & 2 & 10 \\
\hline Kota Blitar & 3 & 9,68 \\
\hline Kab. Kediri & 12 & 8,76 \\
\hline Kab. Jember & 60 & 7,26 \\
\hline Kab. Bojonegoro & 2 & 6,06 \\
\hline Kab. Bangkalan & 15 & 5,56 \\
\hline Kab. Lamongan & 17 & 5,41 \\
\hline Kab. Sumenep & 6 & 4,84 \\
\hline Kota Kediri & 21 & 4,29 \\
\hline Kab. Jombang & 2 & 2,74 \\
\hline Kota Probolinggo & 0 & 0 \\
\hline Kab. Pacitan & 0 & 0 \\
\hline Kab. Pamekasan & 0 & 0 \\
\hline Kab. Sampang & 0 & 0 \\
\hline Rata-rata & & 24,52 \\
\hline
\end{tabular}

Sumber:Laporan Situasi Perkembangan HIV dan AIDS Dinas Kesehatan Provinsi Jawa Timur Tahun 2017
Tabel 7. Prevalensi HIV pada Pelanggan Penjaja Seks di Jawa Timur Tahun 2017

\begin{tabular}{|c|c|c|}
\hline Kabupaten/Kota & Jumlah & Persentase \\
\hline Kab. Bangkalan & 19 & 100 \\
\hline Kab. Bondowoso & 2 & 100 \\
\hline Kab. Lumajang & 77 & 100 \\
\hline Kab. Ngawi & 2 & 100 \\
\hline Kab. Tuban & 14 & 73,68 \\
\hline Kab. Blitar & 7 & 41,18 \\
\hline Kab. Sumenep & 2 & 40 \\
\hline Kab. Pasuruan & 40 & 39,53 \\
\hline Kab. Tulungagung & 17 & 39,53 \\
\hline Kab. Ponorogo & 3 & 37,50 \\
\hline Kota Madiun & 69 & 37,30 \\
\hline Kab. Situbondo & 2 & 33,33 \\
\hline Kab. Probolinggo & 25 & 31,25 \\
\hline Kota Batu & 4 & 28,57 \\
\hline Kab. Nganjuk & 1 & 25 \\
\hline Kab. Trenggalek & 3 & 25 \\
\hline Kab. Sidoarjo & 34 & 16,92 \\
\hline Kota Surabaya & 41 & 15,53 \\
\hline Kota Malang & 33 & 15,21 \\
\hline Kab. Banyuwangi & 29 & 13,54 \\
\hline Kab. Jombang & 1 & 8,33 \\
\hline Kab. Malang & 9 & 8,11 \\
\hline Kab. Gresik & 1 & 7,69 \\
\hline Kab. Kediri & 11 & 7,48 \\
\hline Kota Kediri & 8 & 6,90 \\
\hline Kab. Magetan & 2 & 6,67 \\
\hline Kab. Jember & 24 & 6,54 \\
\hline Kota Mojokerto & 3 & 4,29 \\
\hline Kab. Mojokerto & 1 & 2,22 \\
\hline Kab. Lamongan & 22 & 2,17 \\
\hline Kab. Bojonegoro & 0 & 0 \\
\hline Kota Blitar & 0 & 0 \\
\hline Kota Pasuruan & 0 & 0 \\
\hline Kota Probolinggo & 0 & 0 \\
\hline Kab. Madiun & 0 & 0 \\
\hline Kab. Pacitan & 0 & 0 \\
\hline Kab. Pamekasan & 0 & 0 \\
\hline Kab. Sampang & 0 & 0 \\
\hline Rata-rata & & 25,62 \\
\hline
\end{tabular}

Sumber:Laporan Situasi Perkembangan HIV dan AIDS Dinas Kesehatan Provinsi Jawa Timur Tahun 2017 
Tabel 8. Kaiser Meyer Olkin Test (Uji KMO)

\begin{tabular}{cccc}
\hline \multirow{2}{*}{ KMO Test } & \multicolumn{3}{c}{ Bartlett's of Sphericity } \\
\cline { 2 - 4 } & $\begin{array}{c}\text { Approx Chi } \\
\text { Square }\end{array}$ & df & P-value \\
\hline 0,659 & 68,332 & 21 & 0,012 \\
\hline
\end{tabular}

Tabel 9. Uji Bartlett's of Sphericity

\begin{tabular}{cccc}
\hline \multirow{2}{*}{ KMO Test } & \multicolumn{3}{c}{ Bartlett's of Sphericity } \\
\cline { 2 - 4 } & $\begin{array}{c}\text { Approx Chi } \\
\text { Square }\end{array}$ & df & P-value \\
\hline 0,659 & 68,332 & 21 & 0,012 \\
\hline
\end{tabular}

Hipotesis:

$\mathrm{H}_{0}$ : Tidak terdapat hubungan antarvariabel

$\mathrm{H}_{1}$ : Terdapat hubungan antar variabel

Berdasarkan hasil pengujian Bartlett's of Sphericity diketahui nilai sig. $=0.012($ sig. $<\alpha=0,05)$, maka keputusannya adalah tolak $\mathrm{H}_{0}$ yang artinya terdapat hubungan antar variabel. Asumsi tidak terjadi multikolinieritas tidak terpenuhi sehingga harus dilakukan Analisis Komponen Utama atau Principal Component Analysis.

Berdasarkan hasil analisis komponen utama yang dilakukan untuk mengatasi multikolinieritas dengan bantuan software MINITAB diperoleh skor komponen utama dari data prevalensi HIV pada populasi kunci di kabupaten/kota di Jawa Timur Tahun 2017. Skor komponen utama yang diperoleh tersebut kemudian dianalisis dengan metode cluster $k$-means dengan bantuan software SPSS dan diperoleh nilai Kaiser-Meyer-Olkin (KMO) dari skor komponen utama adalah 0.5 yang berarti bahwa sampel sudah representatif atau sudah mewakili populasi sehingga dapat dilanjutkan ke analisis Cluster K-Means.

\section{Analisis Cluster K-Means}

Wilayah kabupaten/kota yang memiliki karakteristik yang sama dapat dibentuk sebuah cluster dan dianalisis dengan metode cluster $K$-Means (Nasari \& Darma, 2015). Terdapat 3 cluster yang dihasilkan untuk pengelompokan kabupaten/kota di Jawa Timur berdasarkan jumlah populasi kunci yang mengidap HIV yaitu cluster 1 atau kategori waspada, cluster 2 atau kategori awas dan cluster 3 atau kategori siaga. Kategori tersebut merupakan inovasi peneliti.

Dari tabel 10, dapat diketahui mengenai data Centroid yang merupakan rata-rata prevalensi HIV pada populasi kunci di Jawa Timur. Selanjutnya dapat diketahui pula pada kluster 1 atau kategori waspada yang terdiri dari prevalensi HIV ibu hamil sedang, prevalensi HIV WPS rendah, prevalensi HIV waria rendah, prevalensi HIV LSL rendah, prevalensi HIV IDU rendah, prevalensi HIV pasangan risti sedang dan prevalensi HIV pelanggan PS rendah.

Selanjutnya pada kluster 2 atau kategori awas yang terdiri dari prevalensi HIV ibu hamil tinggi, prevalensi HIV WPS sedang, prevalensi HIV waria sedang, prevalensi HIV LSL tinggi, prevalensi HIV IDU sedang, prevalensi HIV pasangan risti tinggi dan prevalensi HIV pelanggan PS tinggi.

Pada kluster 3 atau kategori siaga yang terdiri dari prevalensi HIV ibu hamil rendah, prevalensi HIV WPS tinggi, prevalensi HIV waria sedang, prevalensi HIV LSL sedang, prevalensi HIV IDU tinggi, prevalensi HIV pasangan risti sedang dan prevalensi HIV pelanggan PS sedang.

\section{Anggota setiap Cluster}

Berdasarkan hasil analisis diketahui jumlah anggota dari pengelompokan ketiga cluster adalah cluster 1 atau kategori waspada sebanyak 4 kabupaten/kota, cluster 2 atau kategori awas

Tabel 10. Final Cluster Centers

\begin{tabular}{lcccc}
\hline \multirow{2}{*}{ Variabel } & \multirow{2}{*}{ Centroids } & \multicolumn{3}{c}{ Cluster } \\
\cline { 3 - 5 } & & $\mathbf{1}$ & $\mathbf{2}$ & $\mathbf{3}$ \\
\hline HIV Ibu & 0,24 & 0,15 & 0,47 & $-0,24$ \\
Hamil & & & & \\
HIV WPS & 13,46 & $-44,64$ & 18,43 & 24,64 \\
HIV Waria & 15,23 & $-16,51$ & 16,88 & 24,06 \\
HIV LSL & 22,06 & 0,52 & 27,38 & 18,15 \\
HIV IDU & 5,18 & 4,24 & 4,37 & 7,64 \\
HIV Pasris & 24,51 & 21,29 & 28,48 & 16,33 \\
HIV PPS & 28,25 & 20,61 & 29,86 & 27,85 \\
\hline
\end{tabular}


Tabel 11. Hasil Pengelompokan 38 Kabupaten/ Kota Berdasarkan Prevalensi HIV pada Populasi Kunci

\begin{tabular}{|c|c|c|}
\hline Cluster & Kategori & Kabupaten/Kota \\
\hline 1 & Waspada & Kab. Bondowoso \\
\hline 1 & Waspada & Kab. Pasuruan \\
\hline 1 & Waspada & Kab. Situbondo \\
\hline 1 & Waspada & Kab. Trenggalek \\
\hline 2 & Awas & Kab. Bangkalan \\
\hline 2 & Awas & Kab. Banyuwangi \\
\hline 2 & Awas & Kab. Gresik \\
\hline 2 & Awas & Kab. Jember \\
\hline 2 & Awas & Kab. Jombang \\
\hline 2 & Awas & Kab. Kediri \\
\hline 2 & Awas & Kota Kediri \\
\hline 2 & Awas & Kota Malang \\
\hline 2 & Awas & Kota Mojokerto \\
\hline 2 & Awas & Kota Pasuruan \\
\hline 2 & Awas & Kota Probolinggo \\
\hline 2 & Awas & Kota Surabaya \\
\hline 2 & Awas & Kab. Lamongan \\
\hline 2 & Awas & Kab. Magetan \\
\hline 2 & Awas & Kab. Madiun \\
\hline 2 & Awas & Kab. Malang \\
\hline 2 & Awas & Kab. Mojokerto \\
\hline 2 & Awas & Kab. Nganjuk \\
\hline 2 & Awas & Kab. Pacitan \\
\hline 2 & Awas & Kab. Pamekasan \\
\hline 2 & Awas & Kab. Sampang \\
\hline 2 & Awas & Kab. Sidoarjo \\
\hline 2 & Awas & Kab. Sumenep \\
\hline 2 & Awas & Kab. Tulungagung \\
\hline 3 & Siaga & Kab. Blitar \\
\hline 3 & Siaga & Kab. Bojonegoro \\
\hline 3 & Siaga & Kota Batu \\
\hline 3 & Siaga & Kota Blitar \\
\hline 3 & Siaga & Kota Madiun \\
\hline 3 & Siaga & Kab. Lumajang \\
\hline 3 & Siaga & Kab. Ngawi \\
\hline 3 & Siaga & Kab. Ponorogo \\
\hline 3 & Siaga & Kab. Probolinggo \\
\hline
\end{tabular}

sebanyak 24 kabupaten/kota dan cluster 3 atau kategori siaga sebanyak 10 kabupaten/kota

Berdasarkan tabel 11 diketahui bahwa cluster 1 atau kategori waspada beranggotakan 4 kabupaten/kota yang berarti rata-rata prevalensi HIV pada populasi kunci di wilayah tersebut lebih rendah daripada rata-rata prevalensi HIV pada populasi kunci di Provinsi Jawa Timur. Cluster 2 atau kategori awas beranggotakan 24 kabupaten/kota yang berarti rata-rata prevalensi HIV pada populasi kunci di wilayah tersebut lebih tinggi daripada rata-rata prevalensi HIV pada populasi kunci di Provinsi Jawa Timur. Sedangkan Cluster 3 atau kategori siaga beranggotakan 10 kabupaten/kota yang berarti rata-rata prevalensi HIV pada populasi kunci di wilayah tersebut berada disekitaran rata-rata prevalensi HIV pada populasi kunci di Provinsi Jawa Timur.

Pada kabupaten/kota dengan kategori kluster waspada, tes dan konseling HIV diprioritaskan pada ibu hamil dengan keluhan IMS dan TB. Sedangkan pada kabupaten/kota dengan kategori kluster siaga dan awas, tes dan konseling HIV wajib dilaksanakan pada semua populasi kunci dan semua ibu hamil.

\section{PEMBAHASAN}

\section{Pengelompokan Kabupaten/Kota di Jawa Timur Berdasarkan Prevalensi HIV pada Populasi Kunci}

Menurut Profil Kesehatan Jawa Timur tahun 2017, Provinsi Jawa Timur termasuk dalam level epidemik HIV terkonsentrasi yang dibuktikan dengan prevalensi HIV pada ibu hamil sebesar $<1 \%$ dan pada poplasi kunci sebesar $\geq 5 \%$ (Dinkes Provinsi Jawa Timur, 2018). Tingginya angka prevalensi HIV tersebut dapat menimbulkan berbagai efek jangka panjang, misalnya epidemi HIV/AIDS di Papua saat ini mempengaruhi unsur demografi. Tingginya prevalensi HIV pada kelompok umur lebih muda mengakibatkan produktivitas kerja terganggu serta menurunnya Angka Harapan Hidup (Handayani, 2017).

Kabupaten/Kota di Jawa Timur memiliki jumlah prevalensi HIV pada ibu hamil yang 
tinggi mencapai $3,72 \%$ dan terdapat di 10 kabupaten/kota. Persepsi yang berkembang di masyarakat bahwa hanya kelompok tertentu saja yang mengidap HIV, yaitu orang dengan pergaulan seks bebas. Masyarakat perlu diingatkan kembali bahwa virus HIV juga menjangkit banyak ibu rumah tangga yang "baikbaik". Hal ini dikarenakan suami mengidap virus HIV/AIDS akibat hubungan seksual dengan seorang penjaja seks sehingga para istri juga ikut tertular (Handayani, 2017).

HIV di Jawa Timur tidak hanya berkumpul di wilayah perkotaan saja, hal ini dikarenakan mobilitas pengidap HIV yang tinggi dan kemungkinan besar melakukan kontak seksual dengan warga setempat sehingga penularan HIV lebih mudah dan tidak bisa terpantau. Seseorang dengan mobilitas yang tinggi dapat menyebabkan dirinya berada dalam lingkungan yang berisiko (Hugo, 2001). Mobilitas membuat seseorang harus tinggal dan beradaptasi di lingkungan yang baru serta harus mematuhi norma seksual dan sosial yang berbeda.

Penelitian ini sejalan dengan penelitian lain yang mengungkapkan bahwa orang yang sering bepergian ke daerah lain atau tidak menetap di suatu wilayah maka akan rentan terhadap infeksi HIV dan Penyakit Menular Seksual (PMS) lainnya dibandingkan dengan orang yang tidak berpindah atau menetap (Lurie et al., 2003).

Tingginya kasus HIV di suatu daerah juga disumbang melalui infeksi perinatal atau penularan HIV dari ibu hamil ke janinnya. Sebuah studi yang dilakukan sebelumnya menyebutkan bahwa $30 \%$ sampai $38 \%$ bayi yang dilahirkan oleh ibu yang mengidap HIV juga akan mengidap HIV apabila tidak dilakukan program pencegahan (Kulkarni et al., 2011). Hal tersebut tentunya juga menyumbang angka kematian ibu maupun angka kematian bayi.

Orang yang terinfeksi HIV memiliki angka harapan hidup yang rendah apabila tidak menjalani terapi ARV, hal ini dikarenakan penyakit infeksi bawaan yang mudah masuk ke tubuh penderita yang dikenal sebagai infeksi oportunistik seperti diare, TB, pneumonia dan kanker. Hal ini dikarenakan virus HIV akan menyerang sistem kekebalan tubuh penderita sehingga penyakit infeksi mudah masuk ke tubuh penderita.

Prevalensi HIV pada populasi kunci di masing-masing kabupaten/kota di Jawa Timur sangat tinggi dan melampaui ketetapan WHO, bahkan 10 kabupaten/kota termasuk dalam kategori awas dimana hal tersebut sangat penting dan mendesak untuk segera diatasi agar penyebaran dan penularan HIV dapat diminimalisir.

\section{SIMPULAN DAN SARAN}

\section{Simpulan}

Hasil analisis dan pembahasan yang telah dijelaskan, diketahui bahwa sub populasi kunci di Provinsi Jawa Timur tahun 2017 sebagian besar memiliki prevalensi HIV yang sangat tinggi dan melampaui ketetapan WHO. Hal ini menunjukkan bahwa diperlukan kebijakan terkait penanggulangan HIV.

Sebaran wilayah berdasarkan prevalensi HIV pada populasi kunci di Provinsi Jawa Timur tahun 2017 diperoleh 3 cluster optimal yaitu cluster 1 atau kategori waspada dengan anggota 4 kabupaten/kota, cluster 2 atau kategori siaga dengan anggota 24 kabupaten/ kota dan cluster 3 atau kategori awas dengan anggota 10 kabupaten/kota.

\section{Saran}

Berdasarkan hasil penelitian ini, saran yang diberikan peneliti kepada Dinas Kesehatan seProvinsi Jawa Timur adalah melakukan skrining/ tes dan konseling HIV berdasarkan jumlah populasi kunci yang mengidap HIV. Pada kabupaten/kota dengan kategori kluster waspada, tes dan konseling HIV diprioritaskan pada ibu hamil dengan keluhan IMS dan TB. Sedangkan pada kabupaten/kota dengan kategori kluster siaga dan awas, tes dan konseling HIV wajib dilaksanakan pada semua populasi kunci dan semua ibu hamil secara inklusif pada pemeriksaan laboratorium rutin saat pemeriksaan asuhan antenatal atau menjelang persalinan. Selain itu, mengoptimalkan penyediaan layanan perawatan, dukungan dan pengobatan secara adekuat. 


\section{DAFTAR PUSTAKA}

Borkowska-Niszczota, M., 2015. Tourism Clusters in Eastern Poland-Analysis of Selected Aspects of the Operation. Procedia-Social and Behavioral Sciences, 213, pp.957-964.

Dinkes Provinsi Jawa Timur, 2018. Profil Kesehatan Provinsi Jawa Timur Tahun 2017. Surabaya: Dinas Kesehatan Provinsi Jawa Timur.

Gudono, 2014. Analisis Data Multivariat. 4th ed. Yogyakarta: BPFE-Yogyakarta.

Gusty, R.P., Farlina, M., Alfitri, 2015. Studi Fenomenologi Pengalaman Orang HIV/AIDS (ODHA) dalam mendapatkan Dukungan Keluarga di Yayasan Lantera Minangkabau Support Padang. NERS Jurnal Keperawatan, 11(1), pp.22-31.

Handayani, 2017. Waspada Epidemi HIV-AIDS di Indonesia. Medical and Health Science Journal, 1(1), pp.1-8.

Hugo, G., 2001. Mobilitas Penduduk dan HIV/ AIDS di Indonesia. Bangkok: UNDP South East Asia HIV and Development Project.

Kemenkes RI, 2010. Profil Kesehatan Indonesia 2010. Jakarta: Kementerian Kesehatan Republik Indonesia.

Kemenkes RI, 2017. Laporan Situasi Perkembangan HIV dan PIMS di Indonesia Januari-Desember 2017. Jakarta: Direktorat Jenderal Pengendalian Penyakit.

Kulkarni, V., Joshi, S., Gupte, N., Parchure, R., Darak, S., Kulkarni, S., 2011. Declining HIV Prevalence among Women Attending
Antenatal Care in Pune, India. Transactions of the Royal Society of Tropical Medicine and Hygiene, 105(6), pp.315-319.

Lurie, M.N., William, B.G., Zuma, K., MkayaMwamburi, D., Garnett, G.P., Sturm, A.W., Sweat, M.D., Gittelsohn, J., Karim, S.S.A., 2003. The Impact of Migration on HIV-1 Transmission in South Africa: A Study of Migrant and Nonmigrant Men and Their Partners. Sexually Transmitted Diseases, 30(2), pp.149-156.

Muningsih, E., Kiswati, S., 2015. Penerapan Metode K-Means untuk Clustering Produk Online Shop dalam Penentuan Stok Barang. Jurnal Bianglala Informatika, 3(1), pp.1017.

Nasari, F., Darma, S., 2015. Penerapan K-Means Clustering pada Data Penerimaan Mahasiswa Baru. Seminar Nasional Teknologi Informasi dan Multimedia 2015, 3(1), pp.73-78.

Ong, J.O., 2013. Implementasi Algotritma K-Means Clustering untuk Menentukan Strategi Marketing President University. Jurnal Ilmiah Teknik Industri, 12(1), pp.1020.

Rivani, E., 2010. Aplikasi K-Means Cluster untuk Pengelompokkan Provinsi Berdasarkan Produksi Padi, Jagung, Kedelai, dan Kacang Hijau Tahun 2019. Jurnal Mat Stat, 10(2), pp.122-134.

Soemartini, 2008. Principal Component Analysis (PCA) sebagai Salah Satu Metode untuk Menghilangkan Multikolinearitas. Skripsi. Universitas Padjajaran. 